\title{
Dabigatran v praxi - celosvětové setkání odborníků věnované antikoagulační léčbě
}

Ve dnech 11.-12. května 2015 proběhlo v Praze celosvětové setkání předních odborníků v oblasti antikoagulační léčby. Setkání upořádala SPAF Academy (Edukační platforma oborníkù, kteři se zabývají prevencí cévní mozkové príhody u pacientů s fibrilací síní) za podpory společnosti Boehringer Ingelheim. Cílem SPAF Academy je šírení nejnovějších poznatků o prevenci cévních mozkových příhod (CMP) u pacientů s fibrilací síní (FS) a jejich uplatňování v praxi. Celosvětové setkání je vrcholnou akcí SPAF Academy, na kterou navazují regionální akce, což umožňuje efektivní komunikaci výsledků. Přednášky a navazujíci workshopy byly věnovány výsledkům kontrolovaných studií $s$ dabigatranem $v$ prevenci CMP $u$ pacientů $s$ FS a u pacientů se žilní tromboembolií (VTE), nejnovějším dlouhodobým údajům z reálné praxe a také mechanismu účinku idarucizumabu, dosud neschválené protilátky, která blokuje antikoagulační účinek dabigatranu. Souhrn stěžejních přednášek prínášíme $v$ tomto článku.

\section{Body k zapamatování}

- Studie RE-LY prokázala, že dabigatran v dávce 150 mg dvakrát denně snižuje riziko ischemické a zároveň hemoragické CMP v porovnání s warfarinem a v dávce $110 \mathrm{mg}$ dvakrát denně vede ke stejnému snížení rizika CMP jako warfarin při nižším riziku závažného krvácení. Prodloužení studie RELY-ABLE neukázalo žádné nové bezpečnostní signály.

- Dabigatran je první nové perorální antikoagulans (NOAC), které má rozsáhlé údaje z reálné klinické praxe potvrzující jeho dlouhodobou účinnost a bezpečnost prokázanou u pacientů s nevalvulární FS ve studii RE-LY, a to u více než 200000 nových uživatelů dabigatranu a warfarinu.

- V akutní léčbě i v dlouhodobé prevenci recidiv VTE prokázal dabigatran srovnatelnou účinnost $s$ warfarinem a příznivější bezpečnostní profil z hlediska závažného a klinicky významného nezávažného krvácení i jakéhokoliv krvácení.

- Riziko krvácení u elektivních i urgentních operačních zákroků se mezi dabigatranem a warfarinem neliší. Existují doporučené postupy pro operace u osob léčených NOAC. Přínosem pro řešení krvácení u těchto pacientů jsou standardizované nemocniční protokoly.

- Idarucizumab je antidotum dabigatranu, které zajištuje okamžitou, úplnou a trvalou blokádu jeho antikoagulačního účinku. Na kongresu Mezinárodní společnosti pro trombózu a hemostázu (ISTH) v červnu 2015 budou prezentovány první výsledky klinické studie s idarucizumabem u pacientů s krvácením, které dle lékaře vyžaduje antidotum, nebo u pacientů s nutností urgentního operačního zákroku.

\section{Klinický program vývoje dabigatranu a jeho blokády pomocí idarucizumabu}

Jak uvedl doc. dr. John Eikelboom (McMaster University, Ontario, Kanada), NOAC jsou př́kladem inovace v medicíně zavedené do klinické praxe na základě skutečných potřeb pacientů. Cesta dabigatranu k optimální ochraně pacientů s fibrilací síní (FS) před CMP začala v roce 2004, kdy byl zahájen rozsáhlý program klinických studií RE-VOLUTION. V roce 2009 byly prezentovány výsledky základní studie s dabigatranem (RE-LY), na jejichž základě byl tento lék schválen pro prevenci cévních mozkových príhod (CMP) u pacientů s nevalvulární FS (2010 v USA, 2011 v EU). V následujících letech přineslo prodloužené sledování pacientů ze studie RE-LY nazvané RELY-ABLE příznivé výsledky dlouhodobého sledování pacientů léčených dabigatranem. Kontinuální délka sledování byla až 6,7 roku. $V$ roce 2014 , kdy byl dabigatran registrován $v$ této indikaci již ve více než 100 zemích světa, byla na základě studií RE-COVER/RE-COVER II, RE-MEDY a RE-SONATE schválena nová indikace - léčba a prevence recidivy tromboembolické nemoci (TEN). Koncem téhož roku a na začátku roku 2015 přinesly výsledky nezávislé studie amerického Úřadu pro kontrolu potravin a léčiv (FDA) čerpající z databáze Medicare a dalších registrư údaje potvrzující účinnost a bezpečnost dabigatranu v reálné klinické praxi u více než 200000 pacientů s nevalvulární FS - nových uživatelů dabigatranu a warfarinu. V červnu 2015 očekáváme první výsledky studie RE-VERSE AD s idarucizumabem, což je antidotum dabigatranu, které v dosavadních zkoušeních prokázalo okamžité, kompletní a trvalé zvrácení antikoagulačního účinku dabigatranu. I když dabigatran jak v klinických studiích, tak v dosavadní běžné klinické praxi prokazuje lepší bezpečnostní profil, než má warfarin, nebo s ním srovnatelný, krvácení zůstává hlavním nežádoucím účinkem každé antikoagulační léčby. Vývoj antidota vychází hlavně z potřeby řešit krvácení u osob léčených dabigatranem s akutním traumatem nebo urgentní operací. Další výzkum, který přinese nová data z reálné klinické praxe (např. v indikaci TEN), stále probíhá.

\section{Účinnost a bezpečnost dabigatranu $v$ prevenci CMP u nevalvulární FS v kontrolovaných studiích}

Prof. Gregory Y. H. Lip (University of Birmingham, Velká Británie) připomněl výsledky základní studie $s$ dabigatranem (RE-LY) i jejího prodloužení (RELY-ABLE). Po stanovení vhodného režimu dávkování dabigatranu ve studii PETRO bylo do základní studie RE-LY zařazeno 18113 pacientů s FS a jedním či více rizikovými faktory CMP. Pacienti užívali bud' 150 mg nebo 110 mg dabigatranu dvakrát denně (zaslepeno), nebo warfarin v dávce udržující INR 2,0-3,0 (otevřené uspořádání). $K$ dávce dabigatranu $110 \mathrm{mg}$ nebo $150 \mathrm{mg}$ dvakrát denně byli zařazeni pacienti 
bez ohledu na předchozí léčbu, věk, poruchu renálních funkcí, míru rizika krvácení, CMP a primární/sekundární prevenci CMP. Bylo povoleno podávání kyseliny acetylsalicylové a/nebo clopidogrelu a vysazení antikoagulace při chirurgickém zákroku. Díky tomuto uspřádání jsou výsledky studie relevantní pro reálnou klinickou praxi.

Ve studii RE-LY dosáhl dabigatran v dávce $150 \mathrm{mg}$ dvakrát denně v porovnání s warfarinem o $35 \%$ vyšší snížení rizika CMP/systémové embolie (SE) $(p<0,001)$, o $74 \%$ vyšší snížení rizika hemoragických CMP $(p<0,0001)$ a o $24 \%$ vyšší snížení rizika ischemických CMP $(p=0,035)$. V dávce 110 mg dvakrát denně dabigatran zajistil podobný výskyt CMP/ SE jako warfarin, ovšem s o 20 \% nižším rizikem závažného krvácení. Prodloužení studie nazvané RELY-ABLE přineslo údaje o dlouhodobé bezpečnosti dabigatranu (průměrná délka sledování 4,5 roku). Tato studie nenaznačila žádné nové bezpečnostní signály týkající se dabigatranu a potvrdila srovnatelný výskyt CMP a krvácení se základní studií.

Evropská agentura pro léčivé přípravky (EMA) schválila dávkování dabigatranu (150/110 mg) na základě individuálního rizikového profilu pacientů. Post-hoc analýza výsledků studie RE-LY s použitím simulovaného dávkování dabigatranu dle SPC schváleného EMA ukázala následující výsledky: v porovnání s warfarinem vedla léčba dabigatranem $v$ jakékoliv dávce $\mathrm{k}$ poklesu rizika CMP/SE o $26 \%$ a snížení rizika závažného krvácení o $15 \%$ a celkové mortality o $14 \%$ (obr. 1).

\section{Dabigatran v prevenci tromboembolické nemoci}

Doc. dr. Walter Ageno (Università degli Studi dell'Insubria, Varese, Itálie) připomněl, že tromboembolická nemoc je třetím nejčastějším kardiovaskulárním onemocněním po ischemické chorobě srdeční a CMP, která postihne ročně v EU více než 750000 osob. Po prodělané TEN navíc stoupá riziko recidiv. Dabigatran v dávce 150 mg dvakrát denně byl hodnocen ve dvou studiích v léčbě akutní TEN (po iniciální parenterální terapii) v porovnání s warfarinem (RE-COVER a RE-COVER II) a ve dvou studiích v dlouhodobé prevenci recidiv TEN, kdy bylo jeho podávání zahájeno 3-18 měsíců po iniciální antikoagulační léčbě (RE-MEDY vs. warfarin, RE-SONATE vs. placebo). Studie zahrnovaly přes 9000 pacientů.

Souhrn výsledků studie RE-COVER/RE-COVER II prokázal srovnatelnou účinnost dabigatranu s warfarinem v prevenci TEN/fatální TEN při nižším výskytu závažného krvácení o $40 \%$, závažného a klinicky významného o 44 \% i jakéhokoliv krvácení o 33 \%. Podobných výsledkủ bylo dosaženo i ve studii RE-MEDY, kde dabigatran v dlouhodobé prevenci snížil riziko TEN/fatální TEN podobně jako warfarin, a navíc byl spojen s nižším rizikem závažného a klinicky významného nezávažného krvácení o $45 \%$ a jakéhokoliv krvácení o 29 \%. Porovnání s placebem (studie RE-SONATE) ukázalo snížení výskytu TEN/fatální TEN při léčbě dabigatranem o $92 \%$. Výskyt závažných krvácení byl nízký (dva případy u dabigatranu, nulový výskyt u placeba). Ve skupině s dabigatranem byl zjištěn jen očekávaný vyšší výskyt jakéhokoliv krvácení v porovnání s placebem. Př́nos dabigatranu oproti placebu navíc přetrvával i 12 měsíců po ukončení léčby (obr. 2).

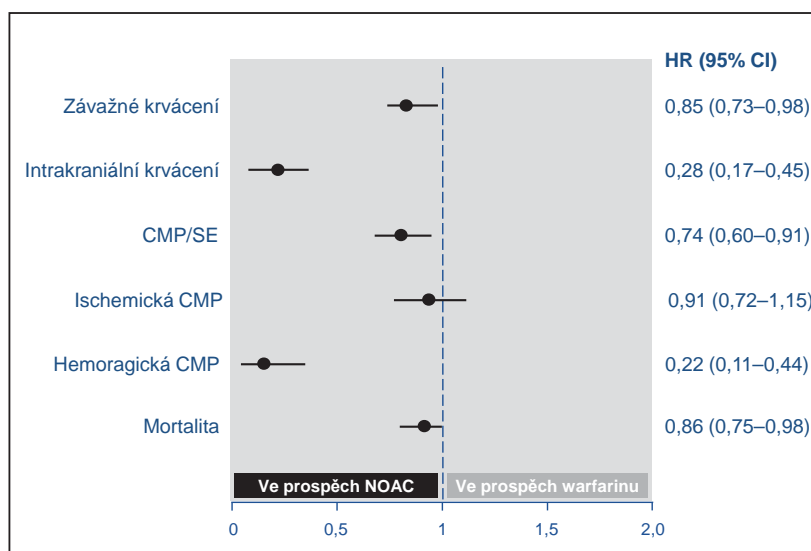

Údaje ze simulované analýzy léčby dabigatranem. Pacienti dostávali dabigatran $150 \mathrm{mg} 2 \times$ denně nebo $110 \mathrm{mg} 2 \times$ denně podle doporučeného dávkování v SPC schváleném v EU.

Lip et al. Thromb Haemost 2014

Obr. 1 - Simulovaný profil účinnosti a bezpečnosti dabigatranu v prevenci CMP při individualizovaném dávkování dle SPC schváleného $v$ EU v porovnání $s$ warfarinem (post-hoc analýza studie RE-LY)

$\mathrm{Cl}$ - interval spolehlivosti; CMP - cévní mozková příhoda; NOAC - nová perorální antikoagulancia; SE - systémová embolie; SPC - souhrn údajů o prípravku.

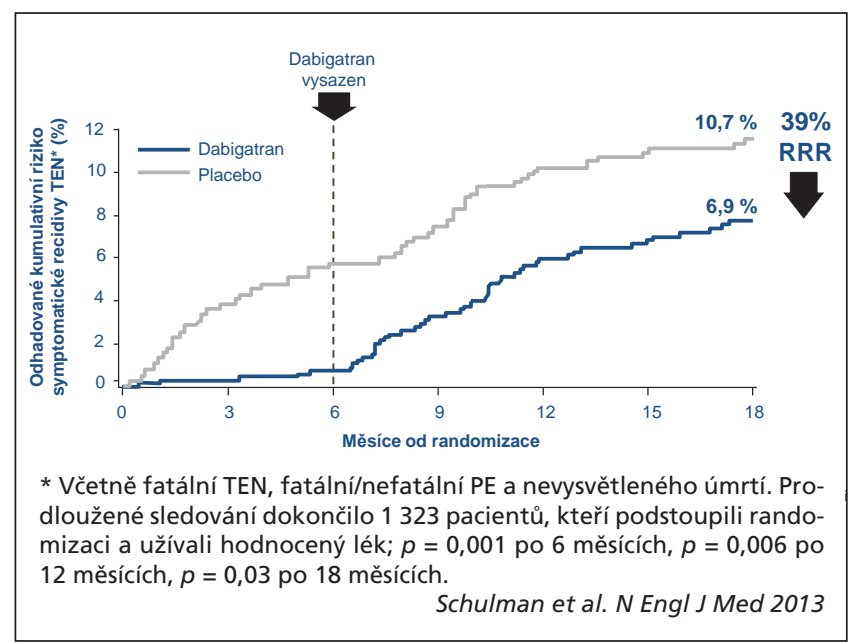

Obr. 2 - Př́nos dabigatranu v prevenci žilní tromboembolie v porovnání s placebem přetrvává i po ukončení léčby (studie RE-SONATE)

PE - plicní embolie; TEN - tromboembolická nemoc.

Doporučená dávka dabigatranu $v$ prevenci recidiv TEN je 150 mg dvakrát denně. Dávka 110 mg dvakrát denně se podává, shodně jako v prevenci CMP u pacientů s nevalvulární FS, pacientům starším 80 let nebo těm, kteří užívají verapamil, a je možná u některých dalších subpopulací. Léčba akutní TEN dabigatranem je zahajována po léčbě $\geq 5$ dní parenterálním antikoagulanciem.

\section{Přínos dabigatranu doložený $\checkmark$ reálné klinické praxi}

O ověření dat z kontrolovaných studií ve skutečných podmínkách každodenní praxe hovořil doc. dr. Todd C. Villines 


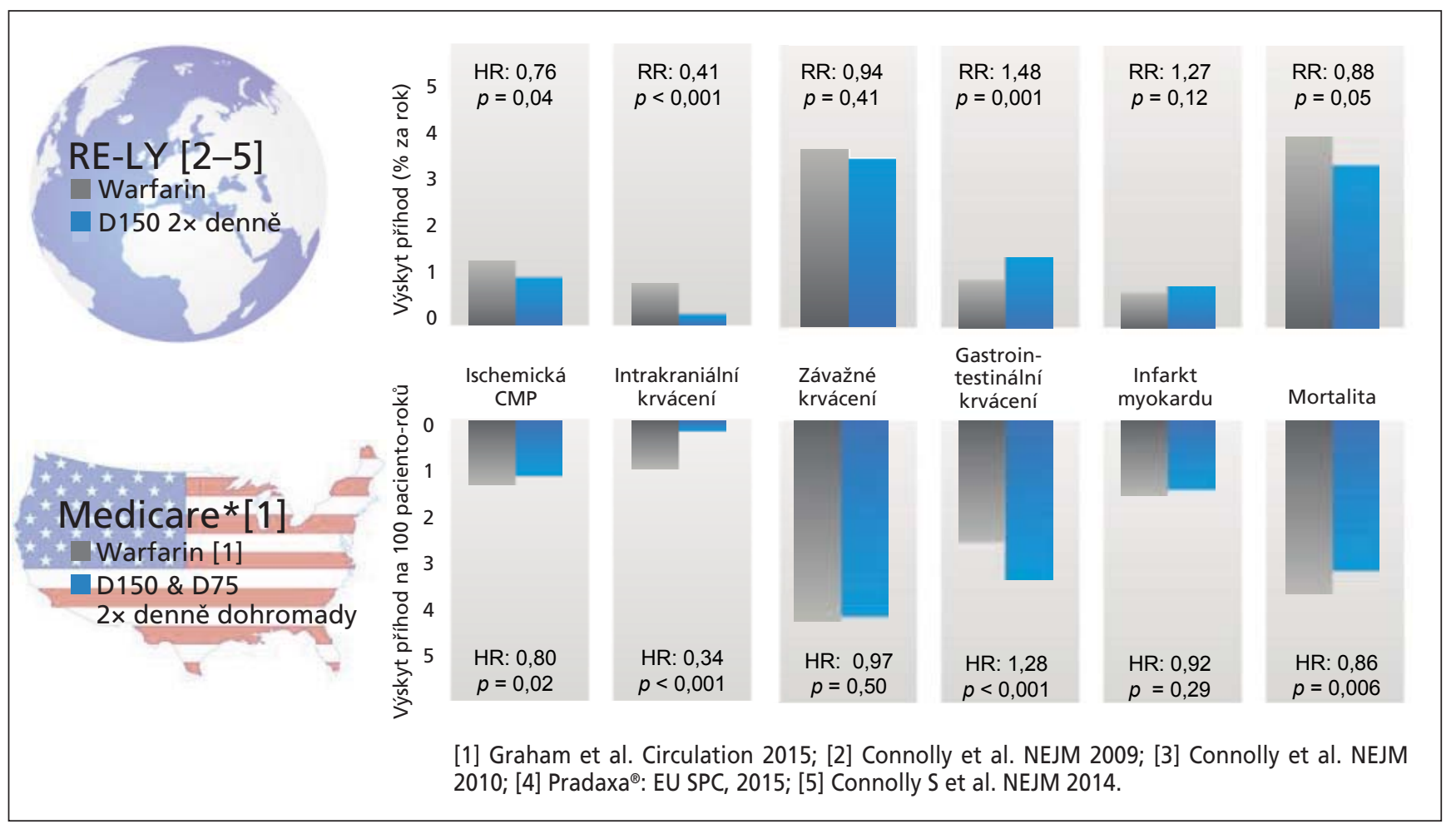

Obr. 3 - Nezávislá analýza údajů FDA z americké databáze Medicare dokládá příznivý poměr přínosů a rizik dabigatranu z kontrolovaných studií v klinické praxi

* Dabigatran $150 \mathrm{mg} / 75 \mathrm{mg}$ 2x denně (dávkování schválené v USA), analýza bez stratifikace dle dávky.

Ve studii RE-LY byl výskyt celkové mortality srovnatelný s warfarinem.

CMP - cévní mozková príhoda.

(Walter Reed National Military Medical Center, Bethesda, USA). Rozsáhlá a dlouhodobá data přinesla nezávislá studie FDA analyzující údaje amerického systému pojištění Medicare. Zahrnovala přes 134000 dosud neléčených pacientů s dabigatranem (150 mg/75 mg dvakrát denně) nebo antagonisty vitaminu K (> 37500 paciento-roků sledování). Jak ukazuje obrázek 3, výsledky týkající se účinnosti i bezpečnosti jsou odrazem výsledků studie RE-LY.

Příznivý bezpečnostní profil dabigatranu potvrdily i předběžné výsledky analýzy dat z databáze Ministerstva obrany USA zahrnující přes 25000 pacientů s nově indikovanou perorální antikoagulační léčbou po 9,8 měsíce sledování a analýzy dat zdravotních pojištoven v USA čítající více než 38000 pacientů, opět nových uživatelů dabigatranu a warfarinu, s délkou sledování 5 měsíců. Evropská data o podávání dabigatranu v reálné praxi přinesl nezávislý dánský registr, který zahrnoval více než 21000 dosud neléčených pacientů $s$ dabigatranem $(150 \mathrm{mg} / 110 \mathrm{mg})$ nebo warfarinem s délkou sledování 13,2 měsíce. Výsledky odpovídají závěrům studie RE-LY i amerických registrů. Dabigatran je tak prvním NOAC, jehož klinický profil byl potvrzen takto rozsáhlými daty z reálné praxe.

\section{Přerušení účinku perorálních antikoagulancií u operací a krvácení}

Problematikou přerušení antikoagulačního účinku při elektivních a urgentních operacích se zabývali prof. $d r$.
James Douketis a prof. dr. Jeffrey Weitz (McMaster University, Ontario, Kanada).

Ve studiích s dabigatranem potřebovalo nejméně jednou přerušit antikoagulační léčbu 25-33 \% pacientů. U pacientů léčených dabigatranem a warfarinem nebyl zjištěn významný rozdíl v krvácení při operačním zákroku. Pro načasování přerušení antikoagulace u elektivních operací je třeba stanovit riziko krvácení a renální funkce pacienta. Evropská arytmologická společnost doporučuje přerušení podávání NOAC jeden až dva dny před výkonem při nízkém riziku krvácení a dva až čtyři dny při vysokém riziku, při glomerulární filtraci $<50 \mathrm{ml} / \mathrm{min} / 1,73 \mathrm{~m}^{2}$ pak dva až tři dny před výkonem při normálním riziku krvácení a čtyři dny při vysokém riziku. Data z reálné praxe ukazují, že přemost́ující antikoagulace je spojena s vyšším rizikem krvácení a nežádoucími účinky.

Jedna z analýz studie RE-LY ukázala, že rozdíl v krvácení mezi pacienty s dabigatranem a warfarinem není patrný ani u urgentních operací. U pacientů léčených NOAC, kteří potřebují urgentní operaci, je třeba při rozhodování vycházet $z$ výsledků koagulačních testů a vyšetření renálních funkcí. U dabigatranu Ize na rozdíl od ostatních NOAC použít standardní antikoagulační test aPTT a jsou známy stropní hodnoty testů (aPTT, dilutovaný trombinový čas), které signalizují, že pacient mưže mít zvýšené riziko krvácení. Je třeba zvážit odsunutí operace nebo opatření k odvrácení antikoagulačního účinku. V mnoha zemích jsou k dispozici oficiální standardy a doporučeny jsou i nemocniční protokoly pro postup při urgentní operaci osob léčených NOAC. 
V případech krvácení u osob léčených NOAC se používají stejné postupy jako při léčbě warfarinem (kromě podání vitaminu K): přerušení podávání NOAC, zjištění zdroje krvácení a udržování dostatečné diurézy. Dostupné jsou obecné algoritmy zástavy krvácení zahrnující podpůrná opatření (mechanické a chirurgické zastavení krvácení, doplnění tekutin, erytrocytů, čerstvé zmražené plazmy, trombocytů) a podání koncentrátu protrombinového komplexu (PCC) nebo aktivovaného PCC u život ohrožujícího krvácení. Př́nosné jsou nemocniční protokoly s podrobným popisem rozhodovacího procesu, které zajištujují účinné a standardizované řešení krvácení.

\section{Idarucizumab - antidotum zajištující rychlou, úplnou a trvalou blokádu účinku dabigatranu}

Údaje o idarucizumabu - protilátce proti dabigatranu, která umožňuje rychle inhibovat jeho antikoagulační účinek v prípadě urgentní operace nebo akutního krvácení, prezentovali $\boldsymbol{d r}$. Joanne van Ryn (Boehringer Ingelheim, Německo) a prof. dr. Peter Verhamme, PhD. (Universitaire Ziekenhuizen Leuven, Belgie).

Idarucizumab představuje poslední pokrok ve vývoji NOAC. Je ve stadiu vývoje a dosud nebyl schválen k užívání nikde na světě. Jde o fragment humanizované proti- látky (Fab), který má 350krát vyšší afinitu k dabigatranu než dabigatran k trombinu. Nemá žádné prokoagulační ani antikoagulační účinky. Podává se jednorázově intravenózně, jeho účinek nastupuje okamžitě a biologický poločas je krátký. V preklinických studiích zajistil idarucizumab významné snížení krevní ztráty a delší přežití zvířat léčených dabigatranem, u myšího modelu pak menší objem hematomu a nižší sedmidenní mortalitu. U zdravých dobrovolníků bylo prokázáno, že idarucizumab zajištuje okamžitou, úplnou a trvalou blokádu antikoagulačního účinku dabigatranu. Tyto účinky byly potvrzeny i u osob s renální insuficiencí (clearance kreatininu 30-90 $\mathrm{ml} / \mathrm{min}$ ) a u starších pacientů (65-80 let). Na kongresu ISTH v červnu 2015 budou prezentovány předběžné výsledky klinické studie s prvním prípravkem, který blokuje účinek NOAC (RE-VERSE AD). Idarucizumab je v této studii podáván i.v. $v$ dávce $5 \mathrm{~g}$ ve dvou samostatných dávkách po $2,5 \mathrm{~g}$ s odstupem 15 minut u pacientů s nekontrolovaným krvácením, které dle lékaře vyžaduje antidotum (např. akutní trauma), a u pacientů vyžadujících urgentní operační zákrok do 24 hodin. Pacienti jsou sledováni 90 dní. Tato studie zahrnuje neselektovaný soubor pacientů, který je reprezentativním vzorkem populace vyžadující blokádu účinku dabigatranu v klinické praxi. Ve vývoji jsou další antidota proti NOAC - andexaet $\alpha$ a aripazin. 